This is an electronic reprint of the original article. This reprint may differ from the original in pagination and typographic detail.

Author(s): Mäkelä, Tiina; Kankaanranta, Marja; Helfenstein, Sacha

Title: $\quad$ Considering Learners' Perceptions in Designing Effective 21st Century Learning Environments for Basic Education in Finland

Year: $\quad 2014$

Version:

Please cite the original version:

Mäkelä, T., Kankaanranta, M., \& Helfenstein, S. (2014). Considering Learners' Perceptions in Designing Effective 21st Century Learning Environments for Basic Education in Finland. The International Journal of Educational Organization and Leadership, 20(3), 1-13. https://doi.org/10.18848/2329-1656/cgp/v20i03/48481

All material supplied via JYX is protected by copyright and other intellectual property rights, and duplication or sale of all or part of any of the repository collections is not permitted, except that material may be duplicated by you for your research use or educational purposes in electronic or print form. You must obtain permission for any other use. Electronic or print copies may not be offered, whether for sale or otherwise to anyone who is not an authorised user. 
Manuscript for Mäkelä, T., Kankaanranta, M. \& Helfenstein, S. (2014). Considering Learners’ Perceptions in Designing Effective 21st Century Learning Environments for Basic Education in Finland, The International Journal of Educational Organization and Leadership, Volume 20, Issue 3, 1-13. Available from http://ijleol.cgpublisher.com/product/pub.264/prod.32

\title{
Considering Learners' Perceptions in Designing Effective 21st Century Learning Environments for Basic Education in Finland
}

\author{
Tiina Mäkelä, University of Jyväskylä, Finland \\ Marja Kankaanranta, University of Jyväskylä, Finland \\ Sacha Helfenstein, University of Jyväskylä, Finland
}

\begin{abstract}
Focusing on so called Key Competences or $21^{\text {st }}$ Century Skills urges educational organizations to redesign their psychosocial and physical learning environments. Inspired by studies indicating that considering learners' perceptions of learning environments can have a positive impact on learning and wellbeing, our study aims at developing design principles for involving learners in the learning environment design. This pilot case study analyzed 7- to 14-years old Finns' $(n=80)$ perceptions by using web questionnaires and design workshops. The results are in line with research indicating that Finnish learners value aspects such as safety and peacefulness, the possibilities for rest and physical activity, the presence of nature, and good social relations. They also value versatile, personally meaningful and collaborative learning situations, including both traditional and novel tools and spaces for learning. The study offers educational administrators tools and data for redesigning learning environments.
\end{abstract}

Keywords: Educational Organization, $21^{\text {st }}$ Century Skills, Learning Environments, Learners' Perceptions, Participatory Design, Design Research

\section{Introduction}

7 The importance of designing psychosocial and physical learning environments is supported by the increasing understanding of the influence of factors such as student wellbeing, quality of teachinglearning interaction, and physical surroundings on learning outcomes and school effectiveness (see e.g., OECD 2009 ${ }^{1}$; UNESCO $2012^{2}$ ). From an institutional viewpoint, learning environments can be considered effective if they support educational organization's mission and objectives (e.g., Guney and $\mathrm{Al}$ 2012), which nowadays commonly consist of so called $21^{\text {st }}$ Century Skills (Binkley et al. 2012) or Key Competencies (European Parliament and Council 2006) such as critical thinking, technological skills, and active citizenship. It is believed that these kinds of learning objectives are best supported by learnercentered "knowledge-building environments" (see Scardamalia et al. 2012), which bridge ubiquitous formal, informal, and non-formal learning situations (Kumpulainen et al. 2010) and where learners can be “designers of their own learning” (Brown 1992, 150; see also Dewey 1899/1980; Vygotsky 1978).

However, existing educational practices and physical infrastructures often obstruct applying these principles. For instance, teacher-centered views of teaching as knowledge transmission prevail (e.g., Cam Aktas 2010; Hutchison 2012) and are fostered by infrastructural elements, such as physical arrangement of classrooms where the teacher's desk is a control and focal point (e.g., Guney and Al 2012; see also Foucault 1975). Further, due to discrepancies between designers', educators', and learners' perceptions, even novel $21^{\text {st }}$ century learning environments may be utilized inefficiently (see van den Akker 2007; Hutchison 2012; Könings et al. 2005).

It is often argued that the gap between the objectives set by educational organizations and the actual outcomes can be diminished by involving various stakeholders in the design process (e.g., van den Akker 2007; Könings et al. 2005). The importance of considering learners' perceptions, in particular, is supported by the research indicating that the congruence between a learner's perception of actual (experienced) and ideal (preferred) learning environment can impact learning positively (Fraser 1998). In addition, we ascertain that to foster competences such as active citizenship, the design process itself should respect the principles of a participatory culture and involve learners in the co-design (i.e. collaborative design) of learning environments with other important stakeholders, all "experts of their experience” (see Sanders and Stappers 2008, 9).

Yet, to date there are only a few cases reported where different stakeholders, and especially learners, have participated in learning environment design (see Ghaziani 2010; UNESCO 2012). Recently, these

\footnotetext{
${ }^{1}$ Teaching and Learning International Survey (TALIS) on effective teaching and learning environments conducted in 23 countries published by OECD (the Organization for Economic Co-operation and Development)

2 a multidisciplinary review of 58 studies on learning environments published by UNESCO (the United Nations Educational, Scientific and Cultural Organization)
} 
initiatives have started to emerge in Finland (see e.g., Kangas 2010; Meskanen 2009; Piispanen 2008), a country in which all citizens, even children, have a right to participate in planning their own "safe, healthy, pleasant, and socially functional living and working environment” (Land Use and Building Act 2000, Chapter 1, Section 5). The mission of Finnish basic education is likewise thought to be best supported by safe, diversified, collaborative, ICT-enhanced, and aesthetically pleasing learning environments, whose design takes into account learners' views (see Finnish National Board of Education 2004, 12-17).

Despite this awareness, aspects such as student participation in decision-making (see e.g., Linnankylä and Malin 2008) and the ICT-enhanced learning (Kankaanranta and Puhakka 2008) continue to be a challenge also in Finland. It has even been suggested that increased student involvement and the use of ICTs could address the rather unique educational challenge, which in Finland is not high dropout rates or generally low academic achievement levels, but low school-satisfaction and engagement levels, particularly amongst some specific learner subgroups consisting primarily of male adolescent students (see Linnankylä and Malin 2008).

This article contributes to addressing the international and national challenge of designing effective environments for $21^{\text {st }}$ century learning by including learners' voices to this discourse and asking students' own views about learning environments conductive to learning and wellbeing. Our study forms part of a wider research collaboration aiming at developing a guiding framework for the design of $21^{\text {st }}$ century learning environments. It consists of various research cycles in educational organizations representing varying cultural contexts. The findings presented in this paper are based on the first research cycle conducted in a Finnish comprehensive school in 2012. It adds to previous Finnish studies especially by focusing more on age and gender differences (see e.g., Kangas 2010).

\section{Conceptual Framework}

Our study employs educational design research approaches, often considered prone to complex, contextdependent problems in real-life settings (Brown 1992; Plomp 2007), including "exploring possibilities for novel learning and teaching environments” (the Design-Based Research Collective 2003, 8) and investigating "how different learning environment designs affect dependent variables in teaching and learning” (Collins et al. 2004, 17). In doing so, these studies typically empower various educational stakeholders (van den Akker 2007).

The preliminary research framework of the study was developed based on multidisciplinary review of research literature and official documents, many of which we have already cited in the introduction. The framework analyses learning environments holistically as complex webs consisting of closely interconnected psychosocial and physical factors that shape the overall conditions for learning and wellbeing in a specific time and space, both physical and virtual (see UNESCO 2012; see also Bronfenbrenner 1994). It entails (a) procedural design principles consisting of the characteristics of design interventions and (b) substantive (content-related) design principles pertaining to the characteristics of effective $21^{\text {st }}$ century learning environments (see also Plomp 2007). During the first research cycle we tested and evaluated the content and construct validity as well as practicality of the preliminary framework to be used and developed further in various educational organizations.

This paper focuses on the development of content-related learning environment design principles. The present understanding about the interrelations between aspects related to overall wellbeing, learning and physical environments (see e.g., UNESCO 2012) led us to divide our preliminary framework in three partially overlapping constructs:

- overall wellbeing including items such as safety, feelings of satisfaction, and good social relations (see e.g., Awartani et al. 2008),

- learning situation focusing more directly on ways of teaching and learning (e.g. personal relevance of contents, teaching methods, and grouping; see e.g., Fraser 1998), and

- learning tools and space design referring to tools and technologies (see e.g. Scardamalia et al. 2012) and characteristics of physical learning environments (see e.g., Ghaziani 2010).

This article presents the main findings of the analysis of all three constructs. A more comprehensive description of the development of the framework is presented elsewhere. Instead of attempting to understand the learner's perception per se, the design principles developed during the first research cycle are the result of collaborative meaning making and knowledge construction with learners (see Scardamalia et al. 2012). During this pilot study we analyzed learners' consensual beta press, in other words shared views, in general as well as between genders and age groups. Nevertheless, private beta press, or private views, were considered when they clearly arose from the data. (See Fraser 1998.) 


\section{Method}

\section{Participants}

Four volunteering teachers and their student groups were recruited for the pilot study from a teacher training school located in Central Finland. This school provides 12 years of primary, lower, and upper secondary education to approximately 1000 children, beginning at the age of 7 (the age when Finnish children start their 9 years of basic education). It promotes its teaching and teacher training mission in a science-based manner and is keen, for instance, to develop a high-quality ICT-learning environment for preparing both young learners and teacher trainees for the needs of a $21^{\text {st }}$ century society. In order to gather data from learners at different ages and schooling stages, the study was conducted with $2^{\text {nd }}$ (girls $n=10$, boys $n=10), 4^{\text {th }}(4,15), 6^{\text {th }}(9,12)$ and $8^{\text {th }}(11,9)$ graders; in total 80 children aged 7 to 14 years $(34$, 46). $4^{\text {th }}$ and $6^{\text {th }}$ graders participated in the study in the late spring 2012 and $2^{\text {nd }}$ and $8^{\text {th }}$ graders in the early fall 2012.

\section{Data Collection}

Multidimensional and rich data were collected through 1) a web questionnaire and 2) design workshops. Materials were designed based on the preliminary framework. Nonetheless, students were encouraged to express freely their views "beyond the framework". Instead of using strongly pre-framed standardized questionnaires (see Fraser 1998), we created a customized questionnaire comprising a total of 35 items rated on a 5-point Likert scale (1=“very little" to 5="very much", for examples see Table 1 in the Result section) and 6 open-ended questions (e.g., the purpose of schooling, personal preferences, good or impossible places to learn, elements that and people who should or should not be present). The language of the questionnaire was kept understandable also for the youngest learners.

During the design workshops, information about varied learning situations was gathered by asking learners to create quick scale models or mock-ups within one situation: learning by 1) studying, 2) doing, 3) socializing, 4) reflecting, or 5) exploring the world (see Table 2 in the Result section). Visuospatial data were supported by half-structured group discussions, during which learners were asked to describe the contents of their space design and express their opinions related to different learning environment dimensions.

\section{Procedures}

Sessions lasting 2 to 3 hours were designed to provide cross-curricular learning experiences for practicing skills needed for participatory $21^{\text {st }}$ century citizenship. They also provided educators professional development opportunities and new ideas for their work. Two researchers conducted sessions together with a teacher, who facilitated the organization, for example, by forming pairs and small groups within each student group. First, collaborative reflection was fostered by filling out the web questionnaire in pairs. Learners were asked to negotiate and seek consensus before grading the Likert statements but to convey both students' opinions on open-ended questions. Work was done in gender-homogeneous pairs (when possible) in order to facilitate the analysis of gender differences.

Second, learners were asked to co-design and create quick scale models mostly out of recycling materials. They worked in five mixed-gender subgroups, and each subgroup was asked to design a space for a specific learning situation. Learners could build any kind of spaces they wished, with the stipulation that they must justify how these spaces provide good conditions for the assigned learning situation. Finally, civic participation was practiced by group discussions held in an authentic partnership with external educational stakeholders (i.e. researchers). In the spring 2012, these discussions were held during the ongoing construction of the scale models in the classroom. In the autumn 2012, we chose to move the group discussions to a separate, more peaceful space.

\section{Data Analysis}

The reliability of findings has been augmented by collaborating with several researchers within a research group and by cross-analyzing different data types. The qualitative data were analyzed, coded, and classified using content analysis techniques. As an example, responses to the open-ended question "What is the most important thing for you at school?" were coded into two main categories, namely answers related to leisure time (e.g., friends, breaks, school meals) versus learning situation (e.g., learning some specific subjects). The coding approach allowed for one or more distinct and significant content elements per received response. With the scale models and transcriptions of group discussions we identified the most common themes and calculated their frequency (e.g., physical activity, presence of nature, 
traditional vs. novel elements). As the objective of the first design cycle was to test our preliminary framework and approach in general and because the sample size (especially for each grade level) was small, at this phase running extensive and multiple statistical tests was not considered relevant. Instead, in the current analysis, numeric trends pertaining to variable distributions (means and standard deviation) and group differences (Independent-Samples $\mathrm{T}$ Test) were only used to support the analysis of the qualitative data. In the following Results section, we have focused our numeric analysis on 19 Likertscale items that clearly could be associated with both the verbal and visuospatial data types.

\section{Results}

Table 1 presents first the mean scores and standard deviation of the Likert-ratings. Due to a slight variation in how the questionnaire was administered, of the total of 43 unique responses on Likert items; 32 came from single-gender pairs, 5 from mixed-gender pairs, and 6 from individuals. In general the students rated the items of all three constructs considerably high, with girls typically giving higher average ratings and exhibiting more homogenous answer patterns than boys.

Second, Table 2 presents 22 scale models constructed during the workshops. They are numbered and referred in the text so that the first number refers to the grade and the second number to the type of learning situation (e.g., $2.1=2^{\text {nd }}$ graders' space for Learning Situation 1 , learning by studying). The scale models constructed represent informal (e.g., 8.4. a lounge), non-formal (e.g., 4.5 a. a gym), and formal (e.g., 2.1. a classroom) learning spaces, both indoor (e.g., 8.3. a café) and outdoor (e.g., 6.3. a park).

The reporting of the results is structured under the three section subheadings each representing one construct of our framework. The numeric findings are linked and presented together with qualitative insights. Content elements extracted from the data are referred to in percentage form so as to facilitate the comparison.

Table 1: Mean scores and standard deviation, $M(S D)$, of the Likert ratings of the positive effect of the items on learning as assessed via a web questionnaire.

\begin{tabular}{|c|c|c|c|c|c|c|c|}
\hline $\begin{array}{l}\text { How much, in your opinion, can the following items } \\
\text { improve and make learning more enjoyable? }(1=\text { very } \\
\text { little, } 2=\text { a little, } 3=\text { some, } 4=\text { much, } 5=\text { very much })\end{array}$ & $\begin{array}{l}\text { All } \\
n= \\
43\end{array}$ & $\begin{array}{c}\text { Girls } \\
n= \\
16\end{array}$ & $\begin{array}{c}\text { Boys } \\
n= \\
22\end{array}$ & $\begin{array}{c}\text { Grade } \\
2 \\
n=10\end{array}$ & $\begin{array}{c}\text { Grade } \\
4 \\
n=10\end{array}$ & $\begin{array}{c}\text { Grade } \\
\quad 6 \\
n=13\end{array}$ & $\begin{array}{c}\text { Grade } \\
8 \\
n=10\end{array}$ \\
\hline \multicolumn{8}{|l|}{ Overall wellbeing } \\
\hline Safety & $4.3(1)$ & $4.7(0.5)$ & $3.9(1.2)$ & $4.9(0.3)$ & $4.2(0.9)$ & $3.8(1.4)$ & $4.4(0.7)$ \\
\hline No behavioral disturbance & $3.8(1.3)$ & $4.1(1.2)$ & $3.5(1.3)$ & $4.3(1.3)$ & $3.9(1.3)$ & $3.8(1.3)$ & $3.2(1.1)$ \\
\hline Enough breaks and rest & $4.2(1.2)$ & $4.6(0.6)$ & $3.9(1.6)$ & $4.4(0.8)$ & $3.9(1.6)$ & $3.9(1.4)$ & $4.7(0.9)$ \\
\hline Good peer relations & $4.3(1)$ & $4.4(0.9)$ & $4.2(1.1)$ & $4.6(0.7)$ & $4(1.3)$ & $4.2(1)$ & $4.6(0.7)$ \\
\hline Good teacher-student relations & $4.2(1)$ & $4.6(0.6)$ & $3.8(1.2)$ & $4.7(0.5)$ & $4(1.2)$ & $3.8(1.3)$ & $4.3(0.7)$ \\
\hline Good home-school relations & $4.2(1.1)$ & $4.3(1.1)$ & $4.0(1.2)$ & $4.9(0.3)$ & $4.6(0.7)$ & $3.7(1.2)$ & $3.7(1.3)$ \\
\hline \multicolumn{8}{|l|}{ Learning situation } \\
\hline Usefulness of studies in own life & $4(1)$ & $4.3(0.8)$ & $3.9(1.2)$ & $4.6(0.7)$ & $3.8(1.3)$ & $3.9(1)$ & $3.8(0.9)$ \\
\hline Designing own learning and learning environments. & $3.8(1.2)$ & $3.9(0.8)$ & $3.6(1.5)$ & $4.3(0.8)$ & $3.8(1.2)$ & $3.3(1.3)$ & $4.1(1.4)$ \\
\hline Teachers' professional skills & $4.1(1.1)$ & $4.5(0.7)$ & $3.7(1.3)$ & $4.3(1.3)$ & $4(1.2)$ & $3.9(1.1)$ & $4.3(0.8)$ \\
\hline Versatile teaching methods & $4.2(1.1)$ & $4.6(0.6)$ & $3.9(1.2)$ & $4.4(0.8)$ & $3.8(1.5)$ & $4.1(1)$ & $4.4(0.8)$ \\
\hline Pair work & $4.1(1.1)$ & $4.4(0.9)$ & $4(1.1)$ & $4.5(0.7)$ & $3.3(1.2)$ & $4(1.2)$ & $4.7(0.5)$ \\
\hline Group work & $3.9(1.1)$ & $4.3(1)$ & $3.5(1)$ & $4(0.9)$ & $3.1(1.1)$ & $4(1)$ & $4.3(0.9)$ \\
\hline Individual work & $3.2(1.4)$ & $3.2(1.5)$ & $3(1.4)$ & $3.7(1.4)$ & $3.5(1.4)$ & $3.2(1.4)$ & $2.4(1.5)$ \\
\hline \multicolumn{8}{|l|}{ Learning tools and space design } \\
\hline Versatile materials & $4(1)$ & $4.2(0.8)$ & $3.8(1.1)$ & $4.1(0.9)$ & $3.9(1.4)$ & $3.8(1)$ & $4.2(0.9)$ \\
\hline Use of technology & $4.1(1.2)$ & $3.8(1.2)$ & $4.3(1)$ & $3.7(1.4)$ & $3.7(1.6)$ & $4(0.8)$ & $4.8(0.4)$ \\
\hline Interesting school books & $4(1.3)$ & $4.3(0.8)$ & $3.8(1.5)$ & $4.4(0.7)$ & $3.8(1.5)$ & $3.8(1.3)$ & $4.1(1.4)$ \\
\hline Luminosity & $4.2(0.9)$ & $4.3(0.8)$ & $4.2(0.9)$ & $4.4(0.8)$ & $3.7(1.1)$ & $4.1(1)$ & $4.7(0.5)$ \\
\hline Spaciousness & $4.2(0.9)$ & $4.3(0.8)$ & $4.2(0.9)$ & $4.3(0.8)$ & $4.1(1.2)$ & $4(0.8)$ & $4.6(0.7)$ \\
\hline Aesthetics & $3.3(1.3)$ & $3.3(1)$ & $3.4(1.4)$ & $3.3(1.3)$ & $3(1.4)$ & $3.4(1.3)$ & $3.7(1.2)$ \\
\hline
\end{tabular}

Note: $\mathrm{n}$ refers here to the number of questionnaires analyzed. Mixed-gender pairings were excluded from the gender-related analysis. 
Table 2: Scale models of learning environments constructed by learners.

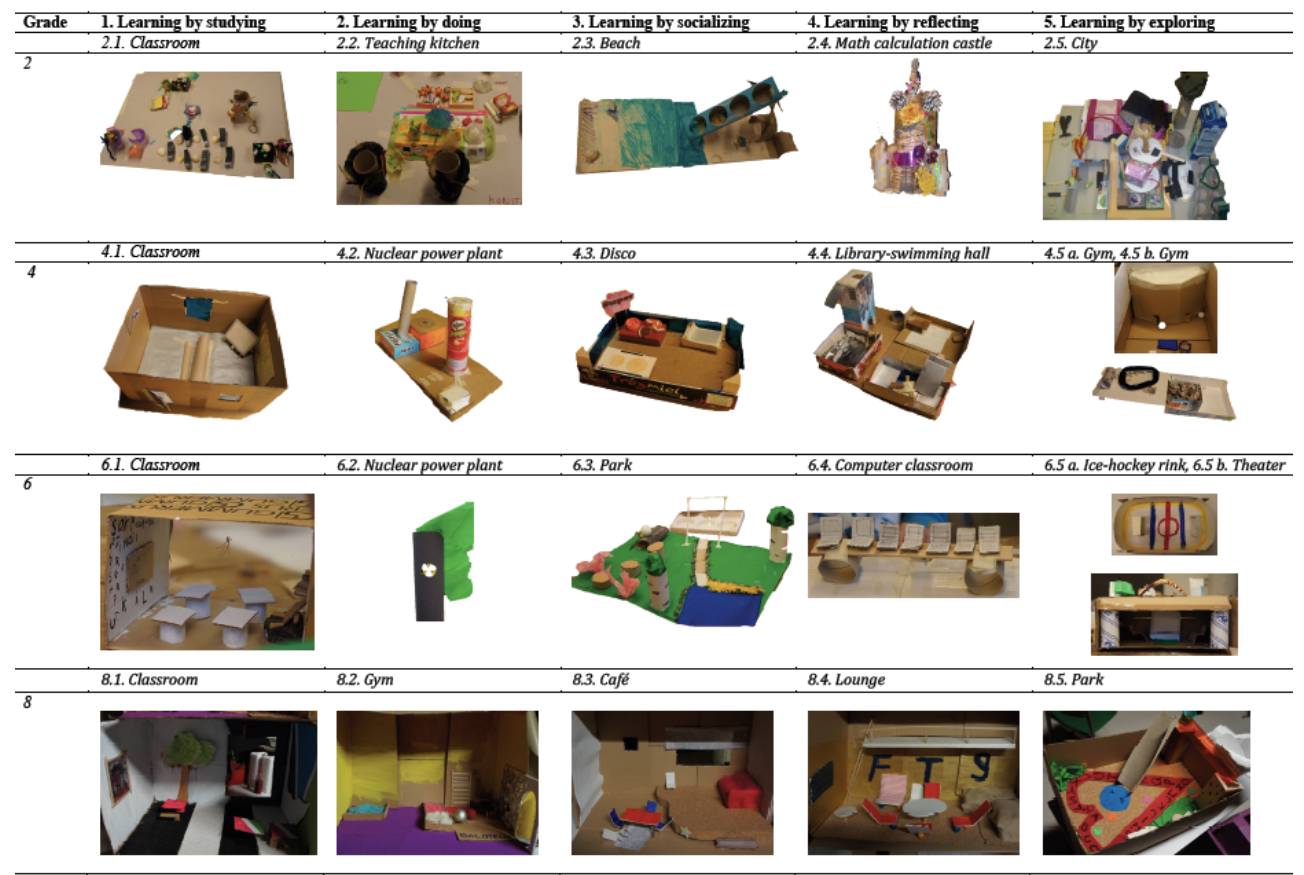

\section{Overall Wellbeing}

Two 4th grade boys: Friends and breaks are the most important things at school.

Two 6th grade girls: It's impossible to learn if you can't concentrate because other people make noise or because you're tired.

As shown in Table 1, learners in general-but significantly more strongly, $\mathrm{t}(35)=3.00, \mathrm{p}=0.006$, the girls $(\mathrm{M}=4.7)$ compared to boys $(\mathrm{M}=3.9)$ —rated highly the item safety. A related item no behavioral disturbance was rated slightly lower $(\mathrm{M}=3.8)$ but with a relatively high variability $(\mathrm{SD}=1.3)$. Also, in the open-ended questions as well as during the group discussions students frequently referred both to safety and security issues (e.g., criminals, guns) and to issues related to a disturbance (e.g., bullying, troublemakers).

Significant as well was the importance placed on ample breaks and rest $(\mathrm{M}=4.2$; Table 1$)$. This result is also supported by the responses received to the question "What is the most important for you at school?”: $57 \%$ of 41 content elements (36 unique responses) were related to leisure time and $43 \%$ to learning situation. The percentage of answers related to leisure time was notably higher in answers received from boys (68\%) than from girls (42\%). The importance of breaks and rest to learners is exemplified in the following excerpt from the conversation with the $8^{\text {th }}$ graders constructing a model of a lounge for learning by reflecting (8.4; Table 2):

Boy 1: This'd be a lounge including sofas and so on.

Boy 2: So after relaxing there, you'll go back to the classes more refreshed.

Researcher: Could you just close your eyes and have a nap there?

Boy 1: Yes, and when opening your eyes, the colorful space gives you energy!

All data types together revealed that in addition to breaks, students consider physical exercise and the presence of nature crucial for their learning and wellbeing. Of the 22 scale models (Table 2), 10 included possibilities for physical activity and 8 featured elements from nature including 6 with water featured prominently. One novel example was the $4^{\text {th }}$ graders' model of a library-swimming hall for learning by reflecting (4.4; Table 2) for which they explained that when getting tired from reading, it is good to go swimming as, after a refreshing swim, it would be easier to concentrate on books again.

Furthermore, the items good peer relations $(\mathrm{M}=4.3)$ and good teacher-student relations $(\mathrm{M}=4.2)$ were deemed important and highlighted in all group discussions. Item good home-school relations was 
rated significantly higher, $\mathrm{t}(41)=-3.55, \mathrm{p}=0.01$, by $2^{\text {nd }}$ and $4^{\text {th }}$ graders in comparison to $6^{\text {th }}$ and $8^{\text {th }}$ graders. The result is also in line with older learners' preference for more autonomy, which was expressed in group discussions.

\section{Learning Situation}

Two 2nd grade girls: We go to school to learn new things.

Two 8th grade boys: We go to school to get a job we like.

In answers to the question "Why do you think we go to school?", as much as $80 \%$ of the 44 content elements (43 unique responses) were related to learning, $11 \%$ to obtaining success in life, and $9 \%$ to schooling as a compulsory duty. Frequently, learning was referred to as something useful and learning contents were criticized as being useless only in few responses. Also the item usefulness of studies in own life was rated relatively high $(\mathrm{M}=4.0$; Table 1$)$. It is interesting that grade $8^{\text {th }}$ pairs were more likely to perceive school as a means to succeed (e.g., professionally, financially) in life (36 \% of 11 content elements) or to report that they attend school because it is obligatory (18\% of content elements).

The item designing own learning and learning environments received only moderate ratings $(\mathrm{M}=$ 3.8; Table 1). Nevertheless, the enthusiasm shown towards the workshops and the comments received from learners imply that learners do value these possibilities. The items teachers' professional skills and versatile teaching methods were rated again highly $(\mathrm{M}=4.1$ and 4.2 ; Table 1$)$. During the group discussions students attached a lot of importance to teachers' role and their comments frequently referred to teacher-led instruction. For example, when discussing with students about the teacher's position in learning spaces, 5 groups expressed that teacher should have their own corner and a table, although the teacher would not be only sitting down but would move around and guide learners. Instead of organizing desks in a circle, it would be better to have teachers in the front so as to enable direct eye contact, reflected $8^{\text {th }}$ grade students designing a classroom (8.1; Table 2). On the other hand, 5 groups were challenging teachers' special position, for example, by suggesting that they should sit at their desk like students or that students should have equally comfortable chairs and furniture as teachers have in the classrooms and staffroom.

The majority of learners valued collaborative learning. Table 1 shows that items pair work $(\mathrm{M}=4.1)$ and group work $(\mathrm{M}=3.9)$ were rated higher than individual work $(\mathrm{M}=3.2)$. The value attached to individual work appeared, however, to have high variability $(\mathrm{SD}=1.4)$. The following excerpt from the conversation with $8^{\text {th }}$ graders documents this in terms of both general preferences as well as how individual preferences may differ:

Researcher: How would you organize your learning spaces?

Girl 1: Nobody would be sitting alone but we'd work more in groups.

Researcher: Do you think that it's nicer to work in groups or pairs instead of working alone?

Girl 1: It's nicer in a group.

Girl 2: I think with a pair.

Researcher: Is it that you don’t like studying alone?

Girl 1: Exactly.

Girl 2: ...well, on the other hand, studying by myself may be easier for me.

\section{Learning Tools and Space Design}

Girl and boy in 6th grade: You can learn everywhere if you want and make an effort.

Boy in 8th grade: Using tablets would bring nice variation to studying.

As Table 1 presents, students rated favorably the items versatile materials $(\mathrm{M}=4)$ as well as both the use of technology $(\mathrm{M}=4.1)$ and interesting school books $(\mathrm{M}=4)$. Technology (e.g., interactive whiteboards, laptops, tablets) was included explicitly in 9 different scale models. Its use was the only aspect where boys $(\mathrm{M}=4.3, \mathrm{SD}=1)$ provided on average higher and more homogeneous ratings than girls $(\mathrm{M}=3.8$, $\mathrm{SD}=1.2$ ). The following excerpt from the discussion with $2^{\text {nd }}$ graders illustrates the typical gender difference rendered statistically significant among $2^{\text {nd }}$ and $4^{\text {th }}$ graders, $t(15)=-2.91, p=0.01$, but not among $6^{\text {th }}$ and $8^{\text {th }}$ graders, $t(18)=0.42, \mathrm{p}=0.68$ :

Researcher: Do you prefer studying using technology or traditional materials?

Boy 1: We should have huge computers to play with!

Researcher: What about tablets and mobiles?

Boy 1: Everyone should have them! 
Boy 2: Yes, it'd be cool!

Researcher: What about girls?

Boy 1: Then we could have LANs...

Girl 1: Something in between.

Girl 2: Also something in between.

Boy 1: ... and play twelve hours, the whole school day!

Girl 1: Twelve hours?

Boy 1: Yes, twelve hours!

Boy 2: Now you've got a point there!

As a whole, $8^{\text {th }}$ graders gave especially high ratings to the use of technology $(M=4.8)$ and their answers were polarized less between genders. In the group discussions both girls and boys expressed both pros and cons (e.g., distraction vs. engagement) concerning ICT-enhanced learning.

Table 1 shows that learners also rated high the items luminosity $(\mathrm{M}=4.2)$ and spaciousness $(\mathrm{M}=$ 4.2). In the group discussions, the youngest learners wished for more space to play, whereas the oldest learners complained about overly cramped spaces or uncomfortably small furniture. Finally, although the item aesthetics received very low scores $(M=3.3$; Table 1$)$, student designs show that learners paid a lot of attention to decoration, colors and beauty (Table 2).

As Table 2 illustrates, all scale models included traditional (e.g., desks, chalkboards) as well as novel (e.g., spacious multipurpose rooms, enormous glass walls) elements. Most of the designs represented elements that are employed already either for Finnish curricular or extra-curricular activities (see Finnish National Board of Education 2004). In addition to canteens (8.3. a café), libraries (4.4), traditional classrooms (2.1, 4.1, 6.1, 8.1), computer classrooms (6.4), typically forming part of all school premises, spaces such as teaching kitchens (2.2) are used already in secondary school. Further, according to the designers, the disco (4.3) could be used for Home Economics and Physical Education. Parks (6.3, 8.5), gyms (4.5 a, 4.5 b, 8.2), ice rinks (6.5 a), and swimming halls (4.4) are also commonly used for Physical Education and recreation. Even nuclear power plants $(4.2,6.2)$-the inclusion of which apparently was influenced by the news regarding their construction in Finland-could be employed for Introduction-toworking-life periods during which time secondary school students work in genuine work environments. The theatre (6.5b), city (2.5), and beach (2.3), in turn, are examples of non-formal or informal environments that are at time destinations for study projects or school trips. (Table 2.)

All in all, younger learners seemed to express more courageously imagination and creativity and boys more so than girls. For example, one group of $2^{\text {nd }}$ graders designed a math calculation castle for learning by reflecting (2.4; Table 2). Another group of $2^{\text {nd }}$ graders envisioned converting the whole school into a bouncy castle. Further, some $2^{\text {nd }}$ grade boys were hoping for chairs that move with electricity and a book that reads by itself.

\section{Discussion}

Although effectiveness of learning environments is goal- and domain-specific and depends on the cultural context and professional traditions of each educational organization (see OECD 2009, 97), learners' perceptions' on ideal learning environments seemed to be very much in congruence with our preliminary framework built on the basis of national and international literature. This makes us think that, even though the sampling approach used in this pilot does not allow statistical generalization of our results, it allowed “'analytical' forms of generalization” (see van den Akker 2007, 49) to be presented in line with contemporary discussions.

1. We found that learners' shared perceptions resonated with studies suggesting that wellbeing, including aspects such as safety and good social relations, affect learning and school satisfaction (e.g., Awartani et al. 2008; OECD 2009). The importance of factors such as good home-school relations, however, seemed to diminish along with older students' growing needs for autonomy. Moreover, students clearly expressed that rest, breaks, socializing, physical exercise, and being close to nature are essential to their wellbeing (similar findings, see e.g., Piispanen 2008; Kangas 2010; Meskanen 2009; Ghaziani 2010). It is interesting that the Finnish school system is known already for considering well these elements (e.g., UNESCO 2012, 36).

2. Learner's perception of the learning situation was in harmony with research suggesting that perceived usefulness of studies to one's own life, as well as varied, collaborative and learner-centered instructional practices, can improve affective and cognitive learning outcomes (e.g., OECD 2009). However, instead of valuing designing one's own learning and learning environments particularly high, learners seemed to give a lot of importance to teacher's role in the design and leadership of teachinglearning interaction. Nevertheless, when learners were given opportunities to express their voice, they were very enthusiastic about it. Hence, considering learners' perceptions can actually mean that self- 
regulated and self-directed learning should be fostered without completely abandoning so called teachercentered practices, such as teacher-regulated instruction (see also Kumpulainen et al. 2012).

3. Similar to other studies (e.g., Kangas 2010), learners seemed to value both traditional and novel tools and spaces for working as well as the ubiquity of learning environments. However, the freshest design ideas came from the youngest learners. If one of the objectives of educational organizations is to foster creativity, more effort may be needed so as not to hinder innovativeness in later years. Moreover, attention should be given to good lighting conditions and learners' wishes for colorful and aesthetically pleasing environments (see also Meskanen 2009; Ghaziani 2010). Finally, there should be enough space for younger learners, in particular, to play (see Ghaziani 2010) and for older learners not to feel uncomfortably crowded.

The overall results are also in line with studies suggesting that girls as a group have more conformist views of school than boys (Moroz 2001; Clay 2008; Linnankylä and Malin 2008). Also, in harmony with other studies (e.g., Moroz 2001), boys in general valued the use of technology more than girls. The gender difference was, however, statistically significant only among younger learners. Our results are also in harmony with other studies suggesting that "efforts to democratize classrooms and allow for greater choice in learning and assessment” (Clay 2008, 35) as well as more versatile use of ICT (see Linnankylä and Malin 2008) could have positive academic and affective impacts especially on subgroups consisting primarily of male and adolescent students with low engagement levels and negative attitudes towards schooling. We think that enhancing opportunities to design one's own learning environments is already a significant step toward more participatory school culture and can contribute to increasing school satisfaction of both genders. Furthermore, based on our findings, we argue that although girls as a whole may need more support in order to develop critical thinking, some subgroups of boys and older learners may need to be guided to convert anti-school attitudes into constructive criticism. Also more efforts may be needed so as to actively support diversified growth of both feminine and masculine identities and thus provide tools to deal with the conformist pressure typical to many organizations (see also Clay 2008).

One could argue that learners tended to interconnect aspects related to their overall wellbeing, learning situation, and physical environment only because of the framework we used and that the interactive knowledge-construction process guided them to do so. Nonetheless, similar observations made in studies using the grounded theory approach (e.g., Kangas 2010) indicate that our results do reflect the learners' perceptions reliably. It is possible, however, that focusing on consensual beta press instead of private beta press led us to construct a less critical and more homogeneous image of learners' perceptions (see Fraser 1998). In the future, more attention could be paid to individual views or to specific student groups such as disengaged learners with school-adverse attitudes.

\section{Concluding Remarks}

The results considered in this article led to the formulation of the collaboratively developed substantive design principles for the effective $21^{\text {st }}$ century learning environments that can be encapsulated into the following characteristics:

- Overall wellbeing:

o safety and peacefulness;

o possibilities to socialize, be physically active, rest and enjoy nature; and

o support for diversified growth towards autonomy,

- Learning situation:

o use of diverse but especially collaborative methods;

o connectedness with students' real-life aspirations; and

o opportunities to make choices related to own learning, and

- $\quad$ Learning tools and space design:

o variable, both traditional and technological tools;

o ubiquitous formal, non-formal, and informal (both indoor and outdoor) learning spaces; and

o luminous, spacious and aesthetic environments.

The power of these design principles lays in the fact that they were co-designed with learners and, therefore, echo their voice. In this sense they are not transferable directly to other educational organizations or cultural settings, but have to be designed collaboratively within every educational organization. Naturally, design principles formulated with different stakeholders can be proved effective only if they are subsequently put into practice. 
All in all, learners' views on psychosocial and physical learning environments conductive to learning and wellbeing seemed to be very realistic and pragmatic. Learners' wishes for both novel and traditional ways, tools and spaces for working also appeared in harmony with the Finnish educational change, which is often considered as evolutionary instead of revolutionary (e.g., Sahlberg 2009). Hence, we think that adding this kind of learners' real-life expertise to the design of the effective $21^{\text {st }}$ century learning environments could even be used to mitigate "overly big innovation ambitions" of some school reformists (see van den Akker 2007, 42).

The design principles developed in this pilot have served already as a base for the design of the second research cycle at the participating teacher training school, in which we have co-designed new social practices and infrastructure for secondary school Natural Science classes (see Mäkelä, Mikkonen, Lundström, 2013). Redesigned and reformed spaces have been deployed and their effectiveness is currently being evaluated. Furthermore, the possible cross-cultural generalizability of our study has been investigated by comparing these results with a similar case study in Spain.

\section{Acknowledgement}

This study was funded by the Finnish Funding Agency for Technology and Innovation (Tekes) through the Indoor Environment Program (2011-2014) and the Finnish Cultural Foundation's Central Finland Regional Fund. We are especially grateful to the teachers and young co-designers at the teacher training school, as well as to various researchers and research assistants, for participating in the study. We also thank professors Anna-Maija Poikkeus and Marja-Kristiina Lerkkanen, from the Faculty of Education, Department of Teacher Education, and staff members of the multidisciplinary Agora Center at the University of Jyväskylä for their support when writing this article. 


\section{REFERENCES}

van den Akker, Jan. 2007. “Curriculum Design Research.” In T. Plomp \& N. Nieveen (Eds.), An Introduction to Educational Design Research. Enschede, the Netherlands SLO: 37-50.

Awartani, Marwan, Cheryl Vince Whitman, and Jean Gordon. 2008. "Developing Instruments to Capture Young People's Perceptions of How School as a Learning Environment Affects of Their WellBeing.” European Journal of Education, 43 (1): 51-70.

Binkley, Marilyn, Ola Erstad, Joan Herman, Senta Raizen, Marting Ripley, Mat Miller-Ricci, and Mike Rumble. 2012. "Defining Twenty-first Century Skills.” In P. Griffin, B. McGaw \& E. Care (Eds.), Assessment and Teaching of $21^{\text {st }}$ Century Skills. Dordrecht: Springer: 17-66.

Bronfenbrenner, Urie. 1994. “Ecological Models of Human Development.” International Encyclopedia of Education, Vol. 3, $2^{\text {nd }}$ Ed: 1643-1647. Oxford: Elsevier.

Brown, Ann, L. 1992. "Design Experiments: Theoretical and Methodological Challenges in Creating Complex Interventions in Classroom Settings.” The Journal of the Learning Sciences, 2(2): 141178.

Cam Aktas, Bilge. 2010. "Investigating Primary School Students' Perceptions Regarding 'Teacher' Through Their Drawings.” The International Journal of Learning, Vol. 17, Num. 8: 408-425.

Clay, Victoria. 2008. "Gender Differences in Measures of Satisfaction with School and General and Academic Self-Concept.” The International Journal of Learning, vol. 15, num. 8: 31-40.

Collins, Allan, Diana Joseph, and Katerine Bielaczyc. 2004. "Design Research: Theoretical and Methodological Issues.” The Journal of the Learning Sciences, 13 (4): 15-42.

The Design-Based Research Collective. 2003. "Design-Based Research: An Emerging Paradigm for Educational Inquiry.” Educational Researcher, Vol. 32, No. 1: 5-8.

Dewey, John. 1899/1980. The School and Society. Carbondale, IL: Southern Illinois University Press.

European Parliament and Council. 2006. "Key Compentences for Lifelong Learning: European Reference Framework.” The Official Journal of the European Union, 30 December 2006/L394.

Finnish National Board of Education. 2004. National Core Curriculum for Basic Education 2004. Vammala, Vammalan Kirjapaino oy.

Foucault, Michel. 1975. Discipline and Punish: the Birth of the Prison. New York: Random House.

Fraser, Barry J. 1998. "Classroom Environment Instruments: Development, Validity and Applications.” Learning Environments Research 1: 7-33.

Ghaziani, Rokhshid. 2010. “School Design: Researching Children’s Views.” Childhoods Today, 4(1), 127.

Guney, Ali, and Selda Al. 2012. "Effective Learning Environments in Relation to Different Learning Theories.” Procedia, Social and Behavioural Sciences 46: 2334-2338.

Hutchison, Alan. 2012. "Mind the Gap: Education Reform Policy and Pedagogical Practice." The International Journal of Educational Organization and Leadership, Vol. 19: 1-12.

Kankaanranta, Marja, and Eija Puhakka. 2008. Kohti innovatiivista tietotekniikan opetuskäyttöä. Kansainvälisen SITES 2006 -tutkimuksen tuloksia. (Towards Innovative Use of Technology in Teaching. Results from the International SITES 2006 Study) Jyväskylän yliopisto: Koulutuksen tutkimuslaitos (University of Jyväskylä: Finnish Institution for Educational Research.

Kangas, Marjaana. 2010. "Finnish Children’s Views on the Ideal School and Learning Environment.” Learning Environments Research 13: 205-223.

Kumpulainen, Kristiina, Leena Krokfors, Lasse Lipponen, Varpu Tissari, Jaakko Hilppö, and Antti Rajala. 2010. Learning Bridges. Toward Participatory Learning environments. Cicero learning. University of Helsinki.

Könings, Karen D., Saskia Brand-Gruwel, and Jeroen, J.G. van Merriënboer. 2005. "Towards More Powerful Learning Environments Through Combining the Perspectives of Designers, Teachers, and Students.” British Journal of Educational Psychology, 75: 645-660.

Land Use and Building Act (132/1999, amendment 222/2003 included) Chapter 1 Section 5. Unofficial translation available from http:/www.finlex.fi/en/laki/kaannokset/1999/en19990132.pdf

Linnankylä, Pirjo and Antero Malin. 2008. "Finnish Students’ School Engagement Profiles in the Light of PISA 2003.” Scandinavian Journal of Educational Research, 52: 6, 583-602,

Meskanen, Sini. 2009. Future School - Designing With Children. Publications in Architecture 2009/100. Helsinki, University of Technology.

Moroz, Wally. 2001. ”Boys Will Be Boys: Implications of Students' Perceptions of Their Learning Environments.” Proceedings of the Learning Conference 2001.

Mäkelä, Tiina, Inka Mikkonen, and Anette Lundström. 2013. “Co-designing 21st Century Secondary School Natural Science Learning Environments.” Case study. European Schoolnet, Brussels. 
OECD. 2009. Creating Effective Teaching and Learning Environments: First Results from TALIS. OECD.

Piispanen, Marika. 2008. “Good Learning Environment. Perceptions of Good Quality in Comprehensive School by Pupils, Parents and Teachers”. University of Jyväskylä. Kokkola University Consortium Chydenius.

Plomp, Tjeerd. 2007. “Education Design Research: an Introduction.” In T. Plomp \& N. Nieveen (Eds.), An Introduction to Educational Design Research. Enschede, the Netherlands SLO: 9-35.

Sahberg, Pasi. 2009. “Educational change in Finland.” In A. Hargreaves, M. Fullan, A. Lieberman \& D. Hopkins (Eds.) International Handbook of Educational Change. Kluwer Academic Publishers.

Sanders, Elizabeth B.N., and Jan Pieter Stappers. 2008. "Co-creation and the New Landscapes of Design.” CoDesign, Taylor \& Francis, March 2008.

Scardamalia, Marlene, John Bransford, Bod Kozma, and Edys. E. Quellmalz. 2012. "New assessment and environments for knowledge building.” In P. Griffin, B. McGaw \& E. Care (Eds.), Assessment and teaching of 21st century skills. Dordrecht: Springer.

UNESCO. 2012. A Place to learn: Lessons from Research on Learning Environments. Technical paper No. 9. Montreal: UNESCO Institute for Statistics.

Vygotsky, Lev Semyonovich. 1978. Mind in Society. The Development of Higher Psychological Processes. (M. Cole, Ed.) Cambridge, MA: Harvard University Press.

\section{ABOUT THE AUTHORS}

Tiina Mäkelä: Ph.D. Student, Faculty of Education and Researcher, Faculty of Information Technology, University of Jyväskylä, Jyväskylä, Finland.

Dr. Marja Kankaanranta: Research Professor, Faculty of Information Technology, Finnish Institute for Educational Research, University of Jyväskylä, Jyväskylä, Finland.

Dr. Sacha Helfenstein: Research Coordinator, Agora Center, University of Jyväskylä, Jyväskylä, Finland. 